\title{
Peter Davies, PhD: A Life Committed to Changing the Face of Alzheimer's
}

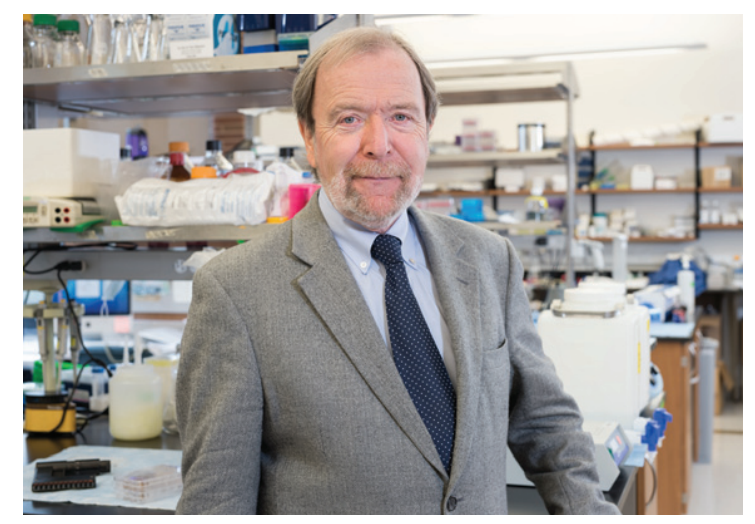

Photo: Peter Davies was always at home in his lab.

The year was 1986 and Peter Davies, a biochemist by training, was about to hold a press conference on his newly-developed tau antibody, ALZ50, at the Society for Neuroscience. He believed the antibody would be critically important in understanding the biology and pathology of Alzheimer's disease. He was bounding up a flight of stairs after one of his then-beloved smokes. He literally jumped when he moved, so excited by the science that it trailed him everywhere.

I was a science writer at Newsday, covering the brain. I had known him for a few years by then. I had just heard that there was an added session at the end of the day. A young scientist from Carlton Gajdusek's lab who was presenting on a newly identified mutation in Alzheimer's and Down syndrome. The talk was at the same time as his press conference.

"Oh, shit," he said in his delicious Welch accent. He canceled the press conference and was in the front row of the auditorium when neuroscientist Dmitry
Goldgaber outlined his findings. They spoke after the talk. A month later, Dr. Goldgaber sent him a Christmas card that included the amino acid sequence of APP. They remained friends and colleagues ever since. Dr. Davies shared the landmark sequence with neurologist and neuroscientist Sam Gandy, and the two immediately ordered peptides.

That was the way in Peter Davies' world. His enthusiasm about the science drove him from his early days in the 1970s when he identified a depletion of acetylcholine in the brains of Alzheimer's patients to the creation of some of the best antibodies in the field. In the last decade of his career, Dr. Davies created an Alzheimer's research center and was working in the lab, of course, but also with patients on immunotherapy drug trials that focused on targeting the abnormal tau protein and inflammation. Throughout it all, Peter Davies remained a Tau guy in a very Amyloid world.

Peter Davies won many battles on the Alzheimer's front but last week lost his battle to a malignant cancer. He was 72 years old and despite being sick, he showed up at the lab several times a week. His respect for the research and love of a great observation never failed to rally him.

"The thing about Peter," said Benjamin Wolozin, $\mathrm{MD}, \mathrm{PhD}$, professor of pharmacology and experimental therapeutics at Boston University School of Medicine, "is that he was a good looking guy who was passionate about his research and had a gift of gab, and everyone adored his accent.” At 21, Dr. Wolozin was looking to start the $\mathrm{PhD}$ part of his dual degree and was told by a professor to look for someone that you will enjoy being around. He knew nothing about Alzheimer's. He showed up for an interview and Dr. Davies went into the cold-room and pulled out a six- 
pack of beer and handed him one and they spent the afternoon talking.

"Peter spoke about his upbringing in Wales. He was the first person in his family to graduate high school. And during college days at the University of Leeds he figured out a way to make easy money by taking aspirin, etching off the letters and selling them as mind-numbing drugs. A chemist in the making. He went on to get his doctoral degree there and moved to the University of Edinburgh for his post-doctoral fellowship in the department of pharmacology. In 1974, he joined the Medical Research Council brain metabolism unit in Edinburgh, and it was there that he began his work in Alzheimer's.

By the early 1970s, L-dopa, a metabolite of dopamine, was approved by the Food and Drug Administration and literally changed life for people with Parkinson's. Peter Davies set out to look for a neurotransmitter that was off kilter in the brains of Alzheimer's patients. He and his colleagues discovered a depletion of cholinergic neurons. Thus was born the acetylcholine hypothesis of Alzheimer's. But acetylcholine wasn't the dopamine of Alzheimer's. It was an early change but not selective for the disease. Still, pharmaceutical companies jumped on the discovery and this led to the first anticholinesterase inhibitors that slow the degradation of acetylcholine. This class of drugs was the first for the field, and remains a mainstay, even though it offers only symptomatic relief, and modestly so.

The finding elevated Peter Davies to center stage in the newly-igniting research world of Alzheimer's. In 1977, he moved to Albert Einstein College of Medicine in the Bronx, where he set out to screen monoclonal antibodies that would identify antigens specific for Alzheimer's. That's when Ben Wolozin showed up in his lab. They had brain tissue from Down syndrome patients who early in adult life developed Alzheimer's. They discovered an antibody that recognized an antigen in the diseased tissue, and called it ALZ50.

"Peter was very careful about jumping to conclusions," Dr. Wolozin said. Dr. Davies went on to develop many more monoclonal antibodies and they would come to learn that it recognized misfolded tau. $\mathrm{MC1}$, a better version of ALZ50, is actually now in the early stages of clinical trials.

His pursuit of all things tau at a time when it was all things amyloid made for some very interesting debates. No one really knew the sequence of events with amyloid-beta and phosphorylated tau. But Dr. Davies was convinced that tau was the key driver of the pathology, not amyloid. "He was hilarious and invincible," said Dr. Wolozin. "He was my Sean Connery. He was enamored with discovery and wanted to find things nobody had identified."

Neuroscientist Michel Goedert, MD, PhD, former head of neurobiology at the MRC Laboratory of Molecular Biology, said he first met Dr. Davies in 1988 and they had similar research interests. Dr. Davies had produced several methods of purifying tau filaments in the laboratory and was always eager to share them. "For us, his tools became very important. We have been working on tau protein for a long time and it is hard to work with. Peter's techniques made it much easier. They bonded because they were both working in the tau camp. Dr. Goedert and his colleagues created a tau-AD animal model using one isoform of tau, as another group had, but Dr. Davies believed that there could be a better model, and he set out to find one. Columbia's Karen Duff, $\mathrm{PhD}$, now back in the United Kingdom, had just created an unusual type of transgenic tau mouse with all six wild type isoforms and she asked Dr. Davies to look at the pathology and help her characterize it. As part of another experiment, he crossed her mouse with a tau knockout and the pathology "just popped out at us," she recalls. "He was ahead of his time in recognizing the importance of tau," said Dr. Duff, who holds him in high regard as her tau mentor. "He is one of my scientific fathers." She started out in the amyloid camp and switched over. When she would try and debate the importance of amyloid, he would have that glint in his eye, shake his head and laugh.

In 2006, Dr. Davies began the last chapter of his career as scientific director of the Litwin/Zucker Center for Research on Alzheimer's Disease at Northwell Health's Feinstein Institute for Medical Research. There, he focused on activation of cell cycle mechanisms in Alzheimer's and developing strategies to target the mutant tau protein and the neuroinflammation of Alzheimer's disease. It was also during this time that he gave up smoking.

"There are few people who contribute important work to more than one aspect of a disease, and Peter is one of them," said Dr. Goedert. In October of 2019 the Rainwater Prize Program awarded Dr. Goedert with its first prize for his contribution to tau research. Peter Davies, who was chair of the selection committee for the award, was looking forward to introducing Dr. Goedert at the Tau 2020 meeting in February. The first day of the two-day meeting, Dr. Davies collapsed and was rushed to the hospital. He had a rare head and neck cancer that had been in remission for five 
years and metastasized last year. He was undergoing chemotherapy, again.

Philippe Marambaud, $\mathrm{PhD}$, a colleague at the Alzheimer's Center, worked with Dr. Davies at Einstein. It was pretty much his first research job. One day, Dr. Davies told him that he was leaving to open a new Alzheimer's center.

"Come with me," his mentor said.

"Of course," said Dr. Marambaud. "I would love to join your lab."

No," Dr. Davies said. "You will not be joining my lab. You will be starting your own." There was no big announcement. Nothing formal. Dr. Marambaud showed up for work at the Feinstein, and started his own lab.

"This quick exchange was a turning point in my career. That is how Peter was, spontaneous and always very generous and supportive," said Dr. Marambaud. "Dr. Davies was not only a giant in the field, but he managed to build an amazing research center that contributed to cement his legacy in the Alzheimer field."

That is not surprising, said David Holtzman, MD, professor and chair of neurology at Washington University in St. Louis. "Peter loved helping young people. He was a character in every positive sense of the word. He was generous, and regardless of what he thought, he listened and talked about things."

Another demonstration of Dr. Davies' love of science and mentoring the next generation has been his involvement from the beginning in the Charleston Conference on Alzheimer's disease, said Alison Goate, DPhil, director of the Ronald M. Loeb Center for Alzheimer's disease at the Icahn School of Medicine at Mount Sinai. A small number of senior scientists (Dr. Davies, Dr. Goate, Joe Halpern, and Randy Nixon) run a mock study section for 15-20 junior scientists nominated by prior participants over a weekend in Charleston and together the group selects a couple of grants to fund. "We work very hard, but there is always time in the evening for the junior scientists to interact with the mentors at dinner and in the bar. This combination of science and vigorous discussion over a drink or a meal put Peter in his element, regaling the audience with stories. Every year we play a game where people anonymously submit improbable things that happened to them in their past and everyone has to guess who did what."

Peter Davies received numerous awards for his research, including the City of New York Liberty Medal, a Lifetime Achievement Award from the International Congress on Alzheimer's Disease (ICAD) and the first Metropolitan Life Foundation Prize.

Betty Diamond, MD, a rheumatologist and director of the Feinstein's Institute of Molecular Medicine, had known Dr. Davies since their Einstein days in the 1980s. She said that only a few months ago he told her that he wanted to take some time off to learn to paint. He had been a photographer for most of his adult life. While he rarely talked about his private life, a few of his photographs hung in his office, along with some photos of his family. "But," he quickly added, "not in the next few years. I won't have time. I have a grant I want to write."

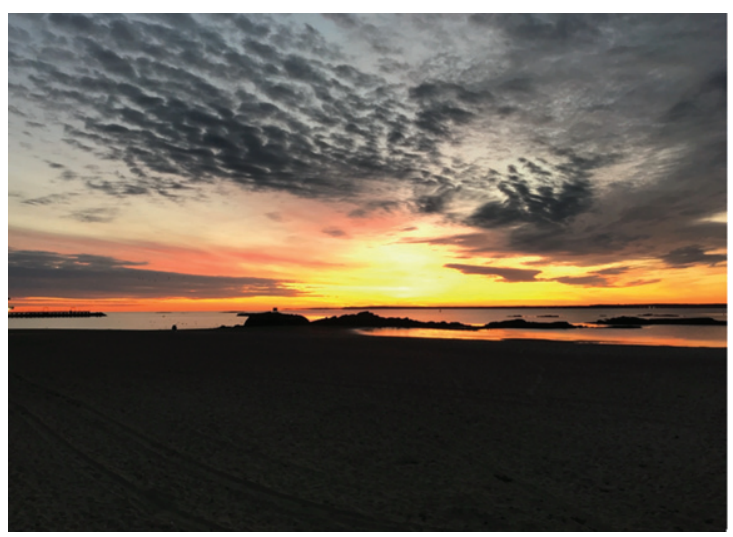

Photo of Sunset: Peter Davies loved taking photos along the water in his hometown of Rye, New York.

Jamie Talan, MPH, assistant professor of science education at The Zucker School of Medicine at Hofstra/Northwell, is a science writer specializing in the brain.E-mail: jtalan3k@aol.com. 